\title{
Increasing the Economic Value of Locally Processed Food
}

\author{
Nahriana $^{1, *}$, Ratnawati T. ${ }^{2}$ \\ ${ }^{1}$ Department of Family Welfare Education, Faculty of Engineering, Universitas Negeri Makassar, Makassar, Indonesia \\ ${ }^{2}$ Department of Family Welfare Education, Faculty of Engineering, Universitas Negeri Makassar, Makassar, Indonesia \\ ${ }^{*}$ Corresponding author.Email: nahriana@unm.ac.id
}

\begin{abstract}
The current pattern of sago availability starts from the sago sales center in the market and is then purchased by the business owners who consume the sago, so it is not difficult for every business owner to obtain sago. When viewed from the protein content, sago has the most superior protein content among staple foods such as rice. The carbohydrate content of sago is relatively higher at 381 per 100 grams. Ruji processed products (dange) are marketed both locally and outside the region, namely in Palopo City. In terms of the marketing mix, there are several strategies, namely: 1) Product strategy, creating new flavor variants and attractive packaging, and what is unique about the culinary business concept is that it is still traditional. 2) Price strategy, the dange price is around Rp. 5000/kg is sold in the form of transparent plastic packaging in the form of a square, and 3) Promotional strategies, in product promotion, namely by selling the products of business owners in the market and also on social media.
\end{abstract}

Keywords: natural resources, traditional culinary

\section{INTRODUCTION}

Palopo City is one of the cities with a high level of demand for sago. The demand for sago in Palopo City is dominated by the processing industry which utilizes sago as a basic ingredient in the manufacture of its products. One industry that is widely spread in Palopo City that utilizes sago in its manufacturing process is the sago processing industry into Ruji (dange) food. Sago in Palopo is usually used as a substitute for rice and other snacks. The type of processed food made from sago that is most popular and consumed by households is dange (ruji) which is a ready-toeat food made from sago in the form of a thin box which is always served with other typical foods[1].

This sago-based dish is a staple food typical of Palopo City, a substitute for rice which is rich in carbohydrates. For diabetics, Ruji (dange) can be a substitute for rice because of its very low sugar content. But unfortunately, many do not know that there is processed sago that can be used as a substitute for rice. One of them is a typical food from Palopo City, namely Ruji (dange). The people of Palopo City are not familiar with this food, because this food is often served at big events. people are not interested in making this a staple food because the bland taste with the pungent smell of sago is the problem. Traditional food or local culinary is a type of food that is closely related to an area and is passed down from generation to generation as part of tradition [2].
One of the opportunities to develop sago is to make various kinds of processed products with high economic value [3]. Many types of food made from sago are produced by people in Palopo. One of the products produced by rural communities is the typical food of the Palopo people, namely ruji (dange). Ruji (dange) is a ready-to-eat food made from sago in the form of a thin box which is always served with other Palopo specialties such as lime, lawa and pocco. Apart from being a source of food, sago is also a source of support for the family's economy and supports most people living in coastal areas. Community life in Palopo cannot be separated from sago plants [4].

Unfortunately, the development of ruji (dange) business into a typical Palopo culinary has not been noticed by the government, even though the contribution of ruji (dange) in Palopo's culinary specialties is also very high because ruji (dange) is a special food that is always on the menus of family events. This is what reduces public interest in developing the production of ruji (dange) in order to provide benefits in a production process because apart from ruji (dange) in the eyes of the government, the government pays less attention to the price of ruji (dange) which is quite cheap. One package of dange containing 15 pieces is usually priced at Rp. 2,000, while the price of other basic foodstuffs is always skyrocketing. Most of the people in Palopo City are pond farmers, but some families run a business for producing ruji (dange) by women as an alternative business to increase family income. 
Consumers are one of the important factors in the success of a business, as well as the Ruji (dange) culinary business, consumers are the main target in the success of the Ruji (dange) culinary business. Consumer behavior is an important thing that must be considered by the Ruji (dange) culinary business actors by paying attention to the behavior of consumers who come to buy dange will make the Ruji (dange) culinary business business that is run to survive and develop well. Based on the description above, the authors are interested in conducting research on "Instant Ruji Local Food Processed Anti-Diabetes Substitute for Rice".

\section{LITERATURE REVIEW}

\subsection{Natural Resources}

Natural resources do not only include the amount of existing materials waiting to be processed and used. But natural resources themselves are also dynamic and changing in nature. Regarding the abundance or not of natural resources, it depends on the time and the right, the level of new techniques and discoveries, the attitude of the people towards these resources, the changes in tastes both at home and abroad. Changes in this variable cause the country to be better or worse off (in terms of its natural resources) even though the physical amount of those natural resources does not change [5].

\subsection{Sago}

Sago has the potential as an alternative food source because it contains a high carbohydrate content, in some areas in Indonesia people consume sago as a staple food other than rice. Sago plants have many advantages compared to other carbohydrate-producing plants, because they can be harvested at any time without regard to the season, are exposed to pests and diseases, the risk is small, and can be harvested sustainably without rejuvenation because sago reproduces by saplings [6].

Many types of food made from sago are produced by people in Palopo. Apart from being a source of food, sago is also a source of support for the family's economy and supports most people living in coastal areas. Community life in Palopo cannot be separated from sago plants [7].

Sago in Palopo is usually used as a substitute for rice and other snacks. The type of processed food made from sago that is most popular and consumed by households is dange (ruji) which is a ready-to-eat food made from sago in the form of a thin box which is always served with other typical foods [14]. According one of the opportunities to develop sago is to make various kinds of processed products with high economic value [16].

\section{3 Tradional Culinery}

Traditional food or local culinary is a type of food that is closely related to an area and passed down from generation to generation as part of tradition. Regional culinary specialties in Indonesia have existed for a long time and have survived to this day, so they are valued as cultural heritage [8].

The attractiveness of a destination is usually related to the ability to meet expectations and tourists. For tourists evaluating the attractiveness of a destination other than climate. Accommodation, natural wealth, history and culture, is also one of the most important experiences to try local food and drinks. Local food, food experiences and culinary tourism, which are important elements of a destination's attractiveness, have received more attention in recent years. Thus, trips to experience destination-specific foods are increasing rapidly and this is called culinary tourism [9].

Many countries are starting to realize the potential of culinary for the welfare of society and the development of tourist destinations. At first, food was only a complement to tourism activities. But then developed a special form of tourism called culinary tourism considering that food is also recognized as an expressive and cultural identity. Food experiences are connected to memories, and these food and souvenir experiences can influence a destination's image and lead to future purchases [10]. The food and beverage industry accounts for $34.33 \%$ of the gross domestic product (GDP). The growth of the food and beverage industry in 2017 reached the level of $9.23 \%$, an increase compared to 2016 of $8.46 \%$ [6].

\section{METHOD}

This study uses a qualitative approach using a qualitative descriptive method. Data analysis techniques that describe, interpret and describe the data collected systematically. The presentation of the data uses thematic analysis from Miles and Huberman to make it more meaningful and easy to understand.

Data collection in this study was conducted by interview, namely semi-structured interviews. Questions in the interview can be added depending on the process and answers during the interview. This interview is expected to reveal how people in Palopo City make Ruji (Dange) their staple food.

\section{RESULT AND DISCUSSION}

From the results of interviews conducted in Palopo City regarding food made from sago, the data obtained can be perceived as facts on the basis of those who are considered capable of providing complete information relevant to the study. Sources of information were obtained from observations of dange culinary business owners in Palopo City. In addition, conclusions according to the results of interviews from the study can be seen below:

Table 1. Interview Result

\begin{tabular}{|c|l|l|}
\hline $\begin{array}{c}\text { N } \\
\text { o. }\end{array}$ & \multicolumn{1}{|c|}{ Statement } & Answer \\
\hline 1 & $\begin{array}{l}\text { How do you get/harvest } \\
\text { sago? } \\
\text { (Data coding: N1) }\end{array}$ & $\begin{array}{l}\text { I get sago from sago } \\
\text { farmers, sometimes I buy it } \\
\text { at the market. }\end{array}$ \\
\hline 2 & $\begin{array}{l}\text { Do you have threats and } \\
\text { obstacles to the } \\
\text { availability of raw } \\
\text { materials? } \\
\text { (Data coding: N2) }\end{array}$ & $\begin{array}{l}\text { The obstacle may be in } \\
\text { terms of selling sago in the } \\
\text { market because I only buy } \\
\text { it at the market and the } \\
\text { lack of land and tools to } \\
\text { support the production of }\end{array}$ \\
\hline
\end{tabular}




\begin{tabular}{|c|l|l|}
\hline 3 & $\begin{array}{l}\text { How is the distribution of } \\
\text { sago plants in your area? } \\
\text { (Data coding: N3) }\end{array}$ & $\begin{array}{l}\text { In this area, only a few } \\
\text { people have land for crops } \\
\text { and it is very rare to find } \\
\text { people owning sago land } \\
\text { or sago farmers. }\end{array}$ \\
\hline 4 & $\begin{array}{l}\text { What strategies are you } \\
\text { your business? } \\
\text { (Data coding: N4) }\end{array}$ & $\begin{array}{l}\text { The strategy that I do in } \\
\text { developing my business is } \\
\text { to create new flavor } \\
\text { variants and attractive } \\
\text { packaging. }\end{array}$ \\
\hline 5 & $\begin{array}{l}\text { Does your product have } \\
\text { something different that it } \\
\text { deserves to be maintained? } \\
\text { (Data coding: N5) }\end{array}$ & $\begin{array}{l}\text { This product that I have } \\
\text { should be maintained } \\
\text { because it can be used as a } \\
\text { substitute for rice which as } \\
\text { we know is a staple food } \\
\text { source in Indonesia, this } \\
\text { ruji or dange can also be } \\
\text { used as food for dieters } \\
\text { and people who have } \\
\text { diabetes. }\end{array}$ \\
\hline
\end{tabular}

\subsection{Traditional Food from Sago}

Many types of food made from sago are produced by people in Palopo City. Apart from being a source of food, sago is also a source of support for the family's economy and supports most people living in coastal areas. However, from the results of interviews, it was found that in the area here only a few people have plantation land and it is very rare to find people owning sago land or sago farmers.

Sago in Palopo City is usually used as a substitute for rice and other snacks. The type of processed food made from sago that is most popular and consumed by households is dange (ruji) which is a ready-to-eat food made from sago in the form of a thin box which is always served with other typical foods [12].

Currently, the sago farming business in Palopo City is only carried out by farmers as a side business to increase their income, but farmers do not yet know whether this sago farming business can provide benefits for them.

\subsection{Availability of Sago}

The respondents' staple food sources are sago and rice. Although sago is a staple food that was previously more dominantly consumed, currently it is rice that is consumed more by the people in Palopo City. But that does not mean that sago is left for consumption. In general, sago is consumed every day. Not only natives who consume sago, but immigrants also like to consume food made from processed sago.

From the interviews, it was found that the owner of the ruji (dange) business gets sago from sago farmers, sometimes buying it at the market. Food availability is generally sourced from farm production, purchased from the market and from gifts or a combination of the three. For business owners who do not produce sago, they fulfill it from buying at the market [1]. Business owners with high food availability, generally the availability of their rice and sago food from their own production is sufficient until the next harvest [2].

From the results of the interview, it was found that business owners have obstacles in terms of selling sago in the market because they only buy sago in the market and lack of land and tools to support the manufacture of sago. Meanwhile, business owners with low food availability are generally due to limited control over rice fields, low rice production or even not having rice fields and relying solely on purchases.

The results of the availability of food in a household are divided into two, namely the availability for rice and the availability for sago which is a substitute food [7]. Sago is a substitute food other than rice which is very popular in Palopo City, because of its easy presentation and according to them, sago also has good nutritional content, where when eating sago in the form of ruji (dange) it is always accompanied by fish and vegetables with a gravy. This food is an option to be a substitute menu at meal times.

There is no need to worry about the availability of sago because sago is not a perishable material so it can be stored for a year if it is packaged properly in a vacuum sealer, thus sago flour is suitable for export [12].

The availability of sago to business owners in Palopo City, namely by purchasing and processing it yourself. Currently, the availability of sago is mostly obtained by buying directly, because sago farmers have agents who directly buy all the produce from sago farmers. The owner of the Ruji (dange) business in processing sago flour uses family labor in the processing [3]. The current pattern of sago availability starts from the sago sales center in the market and is then purchased by the business owners who consume the sago, so it is not difficult for every business owner to obtain sago.

\subsection{Nutritional Content of Ruji (Dange)}

Ruji (dange) has a very high carbohydrate content. But the difference is, ruji only has low nutritional content, calories, protein, calcium, iron, fiber, fat, carotene, carbonic acid and also thiamin which is in ruji is lower than rice. Although it has lower nutrients than rice, the nutritional content in ruji can compensate for other foods that have higher protein and vitamin content. In addition, although the nutrients in the ruji are lower, the ruji also has many benefits that are good for health. The nutritional content of the ruji can be an alternative as a staple food. Carbohydrates 94 gr. It has about 355 calories $/ 100 \mathrm{~g}, 0.2 \mathrm{~g}$ protein, $0.5 \mathrm{~g}$ fiber, $10 \mathrm{mg}$ calcium and $1.2 \mathrm{mg}$ iron.

Foods that meet the most important nutrients in sufficient quantities to meet the body's needs. Although the human body requires six classes of essential nutrients in its life, the body requires several of them in different amounts at various stages of development [13]. Physical growth includes changes in the balance of the body and besides that it affects the ability of muscles and mental abilities. Growth and development consists of a complex series of changes, starting with the fertilization of the ovary and continuing throughout its entire life [5].

Data in Palopo City shows that all households consume dange every day, especially for the elderly with the aim of having diabetes. There are households that are classified as 
new households consuming sago and making sago a staple food that is consumed daily in large quantities compared to other foods. Rice that replaces sago as a staple food is preferred because it is easy to serve and does not require a lot of side dishes or vegetables as a complement if there are no other complementary foods.

The most dominant component in sago is starch or carbohydrates. This starch is in the form of granules or granules that are shiny white, odorless and tasteless. Starch granules have various shapes and sizes according to their source. Sago starch derived from the extraction of sago $\mathrm{pith} / \mathrm{stem}$ is free from chemicals, is a natural ingredient, suitable for consumption as part of the daily diet and has certain functions in the body's metabolism [10].

As an energy source, sago has the most superior protein content among staple foods such as rice. Compared to rice, the carbohydrate content of sago is relatively higher at 381 per 100 grams. However, sago is a food that is very poor in protein. The protein content of sago is much lower than rice. In terms of vitamin and mineral levels, sago also has lower levels than rice. Realizing the nutritional potential of sago which is not as complete and as good as other staple food ingredients, sago must be consumed together with other ingredients with better nutritional content.

\subsection{Marketing Strategy}

In the interview, it was found that the owner of a ruji culinary business (dange) in developing my business, namely by making new flavor variants and attractive packaging. In connection with this, the marketing strategy of ruji (dange) in the culinary business of ruji (dange) in Palopo City also applies a marketing mix, namely:

\subsubsection{Product strategy}

Dange that has been processed by culinary business owners, the product is always strived to be in the market so that the availability in the market is always there, besides the dange produced has guaranteed quality because it has a very high carbohydrate content. However, dange only contains, calories, protein, calcium, iron, fiber, fat, carotene, carbonic acid and also thiamin which is lower in dange than rice. Although it has lower nutrients than rice, the nutritional content in dange can compensate for other foods that have higher protein and vitamin content. The benefits of dange are for health, including conditioning blood sugar levels, losing weight, maintaining bone health and besides that it can be used as a material for making textiles, foodstuffs, food thickening materials such as noodles and meatballs and animal feed and glucose making materials. In addition, this product should be maintained because the processing is still traditional.From the results of interviews with the owner of the Ruji (dange) culinary business, what is unique about the culi nary business concept is that it is still traditional.

\subsection{Price strategy}

Ruji processed products (dange) are sold in the form of transparent plastic packaging in the shape of a square with a dange price of around Rp. $5000,-/ \mathrm{kg}$

\subsection{Promotion strategy}

From the results of the interview, the strategy carried out in product promotion is by selling the products of business owners in the market and also on social media. In terms of developing their business, namely by making new flavor variants and attractive packaging. This ruji (dange) should be maintained because it can be used as a substitute for rice which as we know is a staple food source in Indonesia, this ruji or dange can also be used as food for dieters and people who have diabetes.

\section{CONCLUSION}

Sago is one of the sources of carbohydrates and basic ingredients in the manufacture of traditional foods in South Sulawesi such as ruji (dange). In general, the cultivation and utilization of sago provide more benefits for Indonesia, both at the level of economic improvement, community welfare, provision of national food commodities, to providing employment and business opportunities. And more importantly, if these efforts are carried out consistently, we can contribute significantly to the world's food supply. For national food, of course, the use of sago as a carbohydrate food commodity will also reduce people's dependence on rice.

\section{ACKNOWLEDGMENTS}

This research has been partially supported by Department of Family Welfare Education, Faculty of Engineering, Universitas Negeri Makassar. And thankyou to support and contribution to this review article so it can be accepted in the International Conference on Social, Economics, Business, and Education (ICSEBE 2021) organized by the University Makassar State (UNM).

\section{REFERENCES}

[1] Junaidi J. dan Zulgani,. 2017. Ekonomi Sumberdaya alam dan Lingkungan (Suatu pendekatan Teoritis).. BPFE-UGM. Yogyakarta.

[2] Hayati, N., R. Purwanti dan A. Kadir W. Preferensi Masyarakat Terhadap Makanan Berbahan Baku Sagu (Rottb) Sebagai Alternatif Sumber Karbohidrat Di Kabupaten Luwu Dan Luwu Utara Sulawesi Selatan. JURNAL Penelitian Sosial dan Ekonomi Kehutanan. 11 (1): $82-90$

[3] Ananda, A. D., \& Susilowati, D. (2017). Pengembangan Usaha Mikro Kecil dan menengah (UMKM) Berbasis Industri Kreatif di Kota Malang. Jurnal Ilmiah Ekonomi, 10, 120-142.

[4] Galvez, MJ Granda, T. Lopez-Guzman dan JR Coronel. 2017. "Gastronomi lokal, budaya dan pariwisata kota berkelanjutan: Perilaku turis Amerika," Kota dan Masyarakat Berkelanjutan, vol. 32, hal.604-612.

[5] Ernawati Endah, dkk. 2018. "Peranan Makanan Tradisisonal Berbahan Sagu Sebagai Alternatif Dalam Pemenuhan Gizi Masyarakat: Kasus Desa Laba, Kecamatan Masamba, Kabupaten Luwu Utara, Provinsi Sulawesi Selatan". Jurnal Volume 14 Program Studi Agribisnis, Departemen Sosial Ekonomi Pertanian, Fakultas Pertanian Universitas Hasanuddin.

[6] Harper, D., 2016. Pangan, Gizi Dan Pertanian. Jakarta: UI-Press

[7] Mulyadi, Rosady., Dorothe Agnes Rampisela., Suryani As'ad., Muh. 'Taufiqurrahman, Rinaldi Sjahril., Makkarennu., Abdul Rahman Nur., Dwi Ratnasari., 
Ratna Maruddin., Andi P. Metaragakusuma. 2017. Studi Awal Pengembangan Sainsteknopark Sagu di Tana Luwu. Prosiding Temu Ilmiah Ikatan Peneliti Lingkungan Binaan Indonesia (IPLBI). 6 : $061-064$.

[8] Nusa, C. 2016. Studi Material Isolator Berbahan Dasar Fly Âsh, Perlit, dan Gypsum. Universitas Halu Oleo. Kendari.

[9] Septian. 2017. Pengaruh Variabel Arah Serat Terhadap Kekuatan Bending pada Komposit Serat Tebu Bermatriks Gypsum dan Resin. Skripsi tidak diterbitkan. Institut Teknologi Sepuluh November. Surabaya.

[10] Ando, H., D. Hirabayashi, K.Kakuda, A.Watanabe, F.S.Jong,andB.H.Purwanto. 2020. Effectsof chemicals fertilizer application onthegrowth and nutrientstatus in leafletofsagopalmatthe rosetstage.J. TropAgr.51:102108

[11] Hasbi, Andi, R dan Sari, H. (2020) Atribut Produk yang Dipertimbangkan dalam Pembelian Olahan Sagu di Kota Palopo. Jurnal Ilmu Pangan dan Hasil Pertanian 4 (1): 7-14.
[12] Fidyansari Dharma dan Haerul J. 2017. "Analisa Usaha Ruji (Dange) Dan Tingkat Kesejahteraan Keluargadi Desa Waelawi Kecamatan Malangke Barat Kabupaten Luwu Utara". Jurnal Volume 5. Program Studi Agribisnis Fakultas Pertanian Universitas Cokroaminoto Palopo.

[13] Yasmin, PA (2018). Industri Makanan dan Minuman Tumbuh 9,23\%. Diakses pada 23 April 2020, dari https://finance.detik.com/industri/d-

3985814/menperinindustri-makanan-dan-minumantumbuh-923

[14] Jumiati N. 2020. Proses Pengolahan dan Pemasaran Tepung Sagu Pada CV. Podomoro Makassar. Jurnal Ilmiah METANSI"Manajemen dan Akuntansi" Volume 3 Nomor 2.

[15] Jones E., 2014. Pembuatan dan Karakterisasi Komposit Serat Kulit Jagung dengan Matriks Epoksi. Medan. Universitas Sumatera Utara

[16] Papilaya, E.C. 2009. Sagu untuk Pendidikan Anak Negeri. IPB Press, Bogor. 